\title{
Bio-Revegetation Impact on the Physicochemical Characteristics of a Sandy Quarry Soil in Terga Beach Region in Algeria
}

\author{
Amina. A. Mouffak ${ }^{1}$, Hassini. Tsaki ${ }^{1}$, Adelkader Bekki ${ }^{2} \&$ Laid Krabia ${ }^{3}$ \\ ${ }^{1}$ Laboratoire d'éco-pédologie, University of Oran, Departement of Biology, Oran, Algeria \\ ${ }^{2}$ Laboratoire de Biotechnologie des Rhizobiums et Amélioration des Plantes, University of Oran, Department of \\ Biotechnology, Oran, Algeria \\ ${ }^{3}$ Institut National des Sols, de l'Irrigation et du Drainage El-Matmar, Relizane, Algeria \\ Correspondence: Amina.A. Mouffak ${ }^{1}$, Laboratoire d'écopédologie, University of Oran, Departement of Biology, \\ BP1524, El Menaouer, Oran, Algeria.Tel: 213-774-577-602.E-mail: fafaanima@gmail.com
}

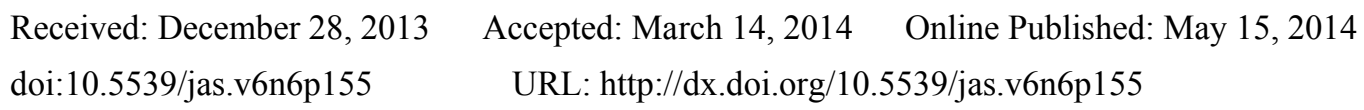

\begin{abstract}
In order to define the impact of a bio-revegetation effect on soil physicochemical properties, we used Acacia Saligna in variants with bio-fertilizers such as rhizobia and mycorrhizae that play a key role in the productivity and sustainability of soil as well as the environmental protection. The area of study is a degraded sandy quarry in Terga, a coastal semi-arid area located in the northwestern part of Algerian. Our sampling and analysis of soil were made after each trimester of experiments in the fields, using four blocks, each one containing ten plots. Sampling is a composite of soil that was made in each plot diagonally on a depth of $10 \mathrm{~cm}$ and a diameter of $30 \mathrm{~cm}$ from the plant, at different times: first trimester ( 3 months), second (6 months), and third (9 months). Preliminary results showed a real and favorable modification of substrates by obtaining materials with less alkaline $\mathrm{pH}$, there is a significant phosphorus increase in the second and third trimester compared to the first trimester, however the soil calcareous nature prevents the expression of some parameters resulting in a small improvement in total nitrogen and a deficiency in both exchangeable magnesium and organic matter.
\end{abstract}

Keywords: sandy quarry, revegetation, Acacia Saligna, rhizobia and mycorrhizal inocula, total nitrogen, available phosphorus

\section{Abbreviations}

Myc: Single endomycorrhizae inoculation. Con: control.

S10, S14, S24: Single Rhizobial inoculation.

D10, D14, D24: Dual Rhizobial + Endomycorhizae inoculation.

Mix: mixed Inoculation with the 3 rhizobial strains (S10+S14+S24) + endomycorhizae.

CT: Total limestone, CA: active limestone, $\mathrm{Ca}$ : exchangeable calcium, $\mathrm{Mg}$ : exchangeable magnesium.

$\mathrm{P}$ : available phosphorus, $\mathrm{N}$ : total nitrogen.

T1, T2, T3: first trimester, second trimester, third trimester.

\section{Introduction}

The soil is the living epidermis of earth, at the interface between the atmosphere, rocks and the living world. It is the meeting point of the plant world, animal and mineral that provides primary production on which human population, flora and fauna depend directly. Soil participates in the great cycles of energy, water and elements (Robert, 1996). It is essential to human activities and the functioning of terrestrial ecosystems. The soil is no longer considered an inert medium. It evolves in space and time. This development gives it variability in its morphological, physical, chemical and biological properties (Collin, 2006). However; it stays a nonrenewable resource because of the long time required for its formation process. Therefore, its preservation and restoration by biological and non-aggressive means to the environment is a major challenge of sustainable development.

In order to re-vegetate a degraded sandy quarry located in Terga (Province of Ain Témouchent in northwest Algeria), Acacia saligna plants with rhizobia (nitrogen fixing symbiont) and mycorrhizal inocula were used. 
Originally from Australia Acacia saligna is a nitrogen-fixing legume, introduced in Algeria, which is characterized by rapid growth and tolerance to drought, salinity and alkalinity; despite the fact that it has a short life varying between 10 and 20 years (Maslin \& McDonald, 2004). However, microbial inocula or bio-fertilizers that have been used on an experimental basis in the soil can be defined as a preparation containing live and efficient microbial cells whose role is to increase the number of these microorganisms, and accelerate microbial processes, thus increasing the assimilation of some plant nutrients such as nitrogen and phosphorus. The goal of our work is to investigate the impact of this bio-revegetation on the soil edaphic aspects over time.

\section{Materials and Methods}

\subsection{Study Area}

The experimental study site, chosen according to its highly degraded character of quarry pit-end operating land, was located in the town of Terga, which extended over an area of $65.07 \mathrm{~km}^{2}$ (average central location at latitude $35^{\circ} 25^{\prime} 07^{\prime \prime}$ North and Longitude $1^{\circ} 10^{\prime} 39^{\prime \prime}$ West). It covered an area of 120 ha located at the mouth of the Oued El Malah, about $7 \mathrm{~km}$ from Terga village (Province of Ain Témouchent). The average altitude of this vast terrace, gently sloping towards the sea, was between 200 and $400 \mathrm{~m}$ (Figure 1).

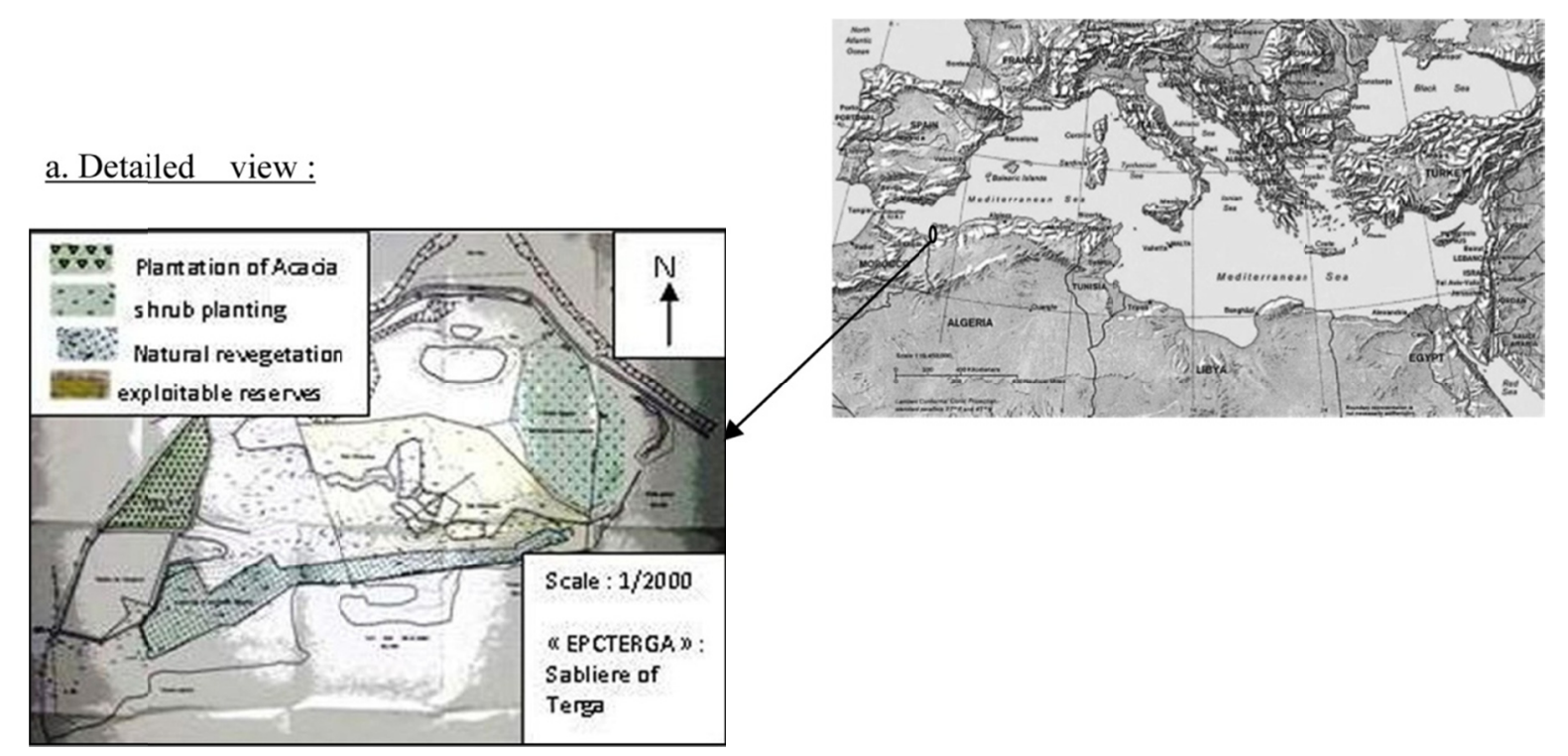

Figure 1. Map location of the study area (scale: $1 / 19.450 .000$; detail:1/2000)

\subsection{Re-Vegetation Site}

The experimental site of the old quarry revegetation contained four blocks, each containing ten plots: A non Acacia Saligna plot (bare soil), an Acacia Saligna plot (control), three plots of Acacia saligna with single rhizobial inoculation with three selected strains: S10, S14 and S24 based on their efficiency in vitro, a plot of Acacia saligna with single mycorrhizae inoculation (Myc), three plots of Acacia Saligna with dual inoculation rhizobial strain S10, S14, S24 + mycorrhizae (D10, D14, D24), and finally a plot of Acacia Saligna with mixed inoculation S10+S14+S24+ mycorrhizae (Mix). The layout of all plots and blocks is shown Figure 2.

\subsection{Materials}

\subsubsection{The Rhizobial Strains}

The bacterial strains were isolated from nodules of Acacia Saligna of 6 plants in natura from Terga area. Each nodule was washed successively with water and then disinfected in sodium hypochlorite $12 \%$ for 1 min and then rinsed 10 times with sterile distilled water. Nodules were crushed under aseptic conditions on YMA medium. However, purification of colonies was obtained after a study of their phenotypic characteristics. Afterward, the best and efficient strains were got via nodulation test and abiotic factors test (Temperature, $\mathrm{pH}$, salinity) (Mansouri, 2011). 


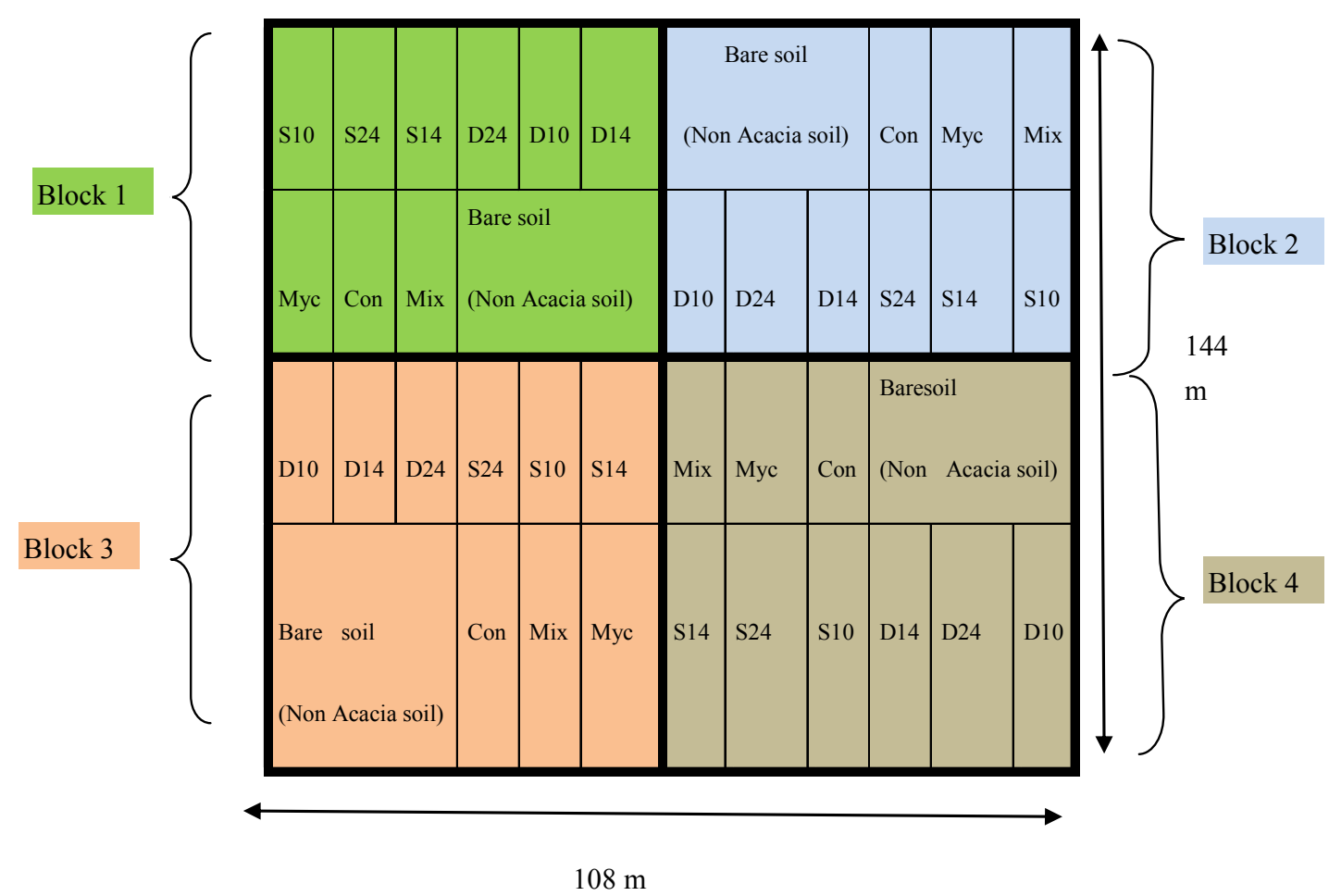

Figure 2. Presentation of the device to test plots distributed in complete blocks in total randomization

\subsubsection{Inoculum Preparation}

An isolated colony was inoculated in an Erlenmeyer flask of $500 \mathrm{ml}$ containing $100 \mathrm{ml}$ of (YMA) broth which was already sterilized at $120^{\circ} \mathrm{C}$ for $20 \mathrm{~min}$ (Vincent, 1970). After 5-7 days of incubation, $100 \mathrm{ml}$ of each inoculum containing about $30 \times 10^{8}$ bacteria/ml was transferred into a $2 \mathrm{~L}$ erlenmeyer flask filled up to $1 \mathrm{~L}$ to allow aeration of medium during agitation (Mansouri, 2011).

\subsubsection{Test Nursery Inoculation}

Acacia Saligna seeds were already scarified with $\mathrm{H}_{2} \mathrm{SO}_{4}$ for $90 \mathrm{~min}$, after they were rinsed with sterile distilled water and then germinated in water agar $0.8 \%$ (Tillard \& Drevon, 1988). After 6 days, seeds were transplanted into plastic bags and then transferred to nursery. The soil used was composed of $25 \%$ of the career's sand and $75 \%$ of peat (Mansouri, 2011). Each $5 \mathrm{ml}$ of a pure culture of rhizobia containing approximately $30 \times 10^{8}$ bacteria/ml was used in the soil at the collar when transplanting. One week after the seedlings, plantlets received a second inoculation (Diouf et al., 2003; Mansouri, 2011).

\subsubsection{Mycorrhizal Inoculums Preparation}

Acacia Salina fresh roots were collected from 7 trees of Acacia Salina in Terga town and 7 other trees in the city of Oran. At each site (Terga and Oran) samples of fine roots were removed from Acacia Saligna root system, and then they were well washed, then submerged in a $20 \% \mathrm{KOH}$ solution for $20 \mathrm{~min}$ at $90^{\circ} \mathrm{C}$. They were then thoroughly rinsed with water and soaked in a $1 \% \mathrm{HCl}$ solution for 5 minutes. Roots were then stained in a solution of $0.1 \%$ trypan blue in lactophenol for 20 minutes (Philipps \& Hayman, 1970). About 50 random fragments of roots thus treated were cut to pieces of about $1 \mathrm{~cm}$ length and compacted between slides and layers. Fragments were then observed under a light microscope 10x40 to estimate the endomycorhizal frequency (Mansouri, 2011).

\subsubsection{Nursery Inoculation Tests}

Roots mycorrhization whose frequency rate was $100 \%$ were used, an application of about $1 \mathrm{~g}$ of fresh endomycorhizal roots against each of the root system at the time of transplanting plantlets (Mansouri, 2011). After 8 months of warehousing in the nursery, the plantlets were transferred to the field (Mansouri, 2011).

\subsection{Sampling}

Sampling is a composite of soil (from reworked materials) that was made in each plot diagonally on a depth of 10 $\mathrm{cm}$ and a diameter of $30 \mathrm{~cm}$ from the plant at different times T1 (3 months), T2 (6 months), and T3 (9 months) 
(Figure 3). The soil is dried in the open air for a week and then crushed and sieved through a diameter of $2 \mathrm{~mm}$ to obtain the fraction of fine soil to perform a set of physico-chemical analysis.

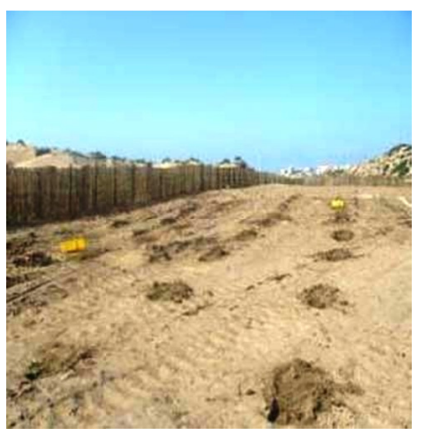

a. Seedlings of Acacia Saligna, the planting day(T0)

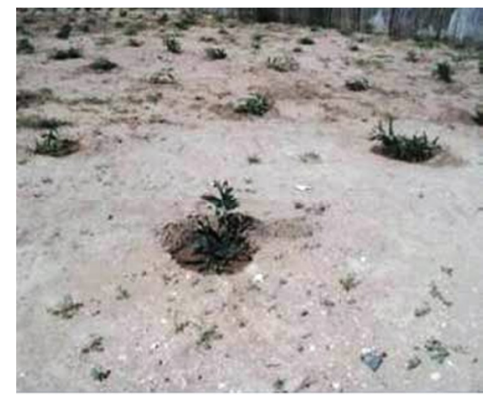

b. Acacia Saligna, 3 months after planting (T1)

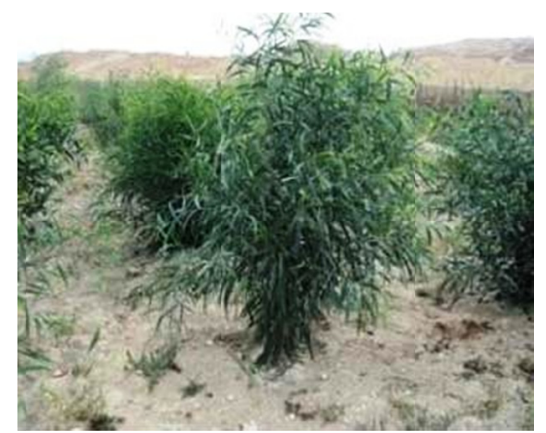

c. Acacia Saligna, 6 months after planting (T2)

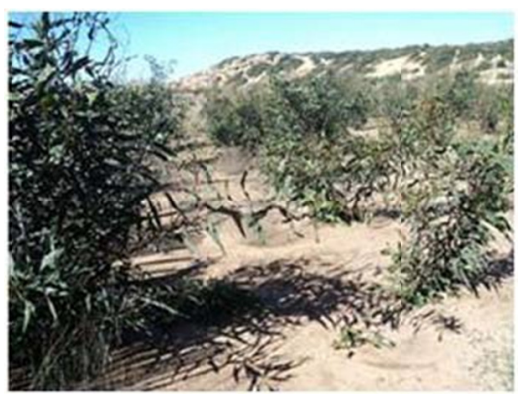

d. Acacia Saligna, 9 months after planting (T3)

Figure 3. Re-vegetation sites at different trimester after plantation T0, T1, T2, T3

\subsection{Physical Analysis}

\subsection{1 $\mathrm{pH}$ Measurement}

About $20 \mathrm{~g}$ of soil was weighed, $50 \mathrm{ml}$ of boiled distilled water was added to it and the mixture was stirred vigorously for 2 hours. The content of the beaker was abandoned then the $\mathrm{pH}$ is measured using a $\mathrm{pH}$ meter after a brief agitation (Aubert, 1978).

\subsection{Chemical Analysis}

\subsubsection{Identification of Organic Matter by Calcination}

The soil sample was dried overnight $(16$ hours $)$ at $150^{\circ} \mathrm{C}$. The crucible was cleaned by heating to red then was cooled in a desiccator for 10 minutes. The empty crucible was weighed, then $10 \mathrm{~g}$ of dried soil was added and the final weight was recorded. Afterward, the soil was calcined in a muffle furnace at $375^{\circ} \mathrm{C}$ for 16 hours. Finally the crucible containing the ashes was cooled in a desiccator and weighed (Centre d'expertise en analyse environnementale du Québec, 2003).

\subsubsection{Measurement of Total Limestone Content by the Bernard Calcimeter}

$1 \mathrm{~g}$ of soil was weighed, and then $5 \mathrm{ml}$ of $\mathrm{HCl}^{1 / 2}$ was introduced into the Bernard calcimeter finger. Next, the soil amount was weighed, and entered into the calcimeter vial after moistening it a little. The vial was closed by connecting to calcimeter, while the liquid of the graduated scale had to beat zero. The flax was then stirred to allow the mixture of the soil with $\mathrm{HCl}$. This agitation resulted in the release of $\mathrm{CO}_{2}$. When the liquid level was stable the $\mathrm{CO}_{2}$ volume was read. The calcimeter was calibrated with pure anhydrous $\mathrm{CaCO}_{3}$ (Aubert, 1978).

\subsubsection{Measurement of Active Limestone Content by Drouineau - Galet Method}

$250 \mathrm{ml}$ of ammonium oxalate $0.2 \mathrm{~N}$ was added to $10 \mathrm{~g}$ of soil, the content was stirred for 2 hours and was filtered. In a $100 \mathrm{ml}$ beaker, $10 \mathrm{ml}$ of the filtrate was poured as well as $10 \mathrm{ml} \mathrm{H}_{2} \mathrm{SO}_{4}$ 1/10. The beaker was placed in an oven at a temperature of $60^{\circ} \mathrm{C}$, afterward it was placed on a magnetic stirrer surmounted by a buret containing potassium permanganate solution $\mathrm{N} / 10$. The permanganate was titrated until we obtained a persistent pink color. $\mathrm{n}$ was the 
number of milliliters of $\mathrm{KMnO}_{4}$ poured. In the same way $10 \mathrm{ml}$ of solution of ammonium oxalate was titrated, $\mathrm{N}$ was the number of milliliters of $\mathrm{KMnO}_{4}$ poured for control (Aubert, 1978).

\subsubsection{Measurement of Total Nitrogen Content by the Kjeldahl Method}

$1 \mathrm{~g}$ of the soil was weighed and was put into a digestion flask containing $12-15 \mathrm{ml}$ of concentrated sulfuric acid $\left(\mathrm{H}_{2} \mathrm{SO}_{4}\right)$, then $7 \mathrm{~g}$ of potassium sulfate and a catalyst as Copper were added, the digestion was brought to a "rolling boil" $\left(370^{\circ} \mathrm{C}\right.$ to $\left.400^{\circ} \mathrm{C}\right)$ and the mixture was heated until white fumes could be seen; then $250 \mathrm{ml}$ of water was added. The $\mathrm{pH}$ mixture was increased, with $45 \% \mathrm{NaOH}$ solution, so the ammonium $\left(\mathrm{NH}_{4}{ }^{+}\right)$ions were converted to ammonia $\left(\mathrm{NH}_{3}\right)$, which was a gas that was distilled and then trapped in a special solution of about $15 \mathrm{ml} \mathrm{HCl}$ in 70 $\mathrm{ml}$ of water. Afterward, an indicator color was added to the trapping solution showing an important amount of trapped acid was still present. Afterward, a standard solution of $\mathrm{NaOH}$ was put into the buret and the trapping acid solution was titrated with the sodium hydroxide solution (Blamir, 2003).

\subsubsection{Measurement of Absorbed Phosphorus by the Olsen Method}

$1 \mathrm{~g}$ of soil was put into a $50 \mathrm{ml}$ erlenmeyer flask, then $20 \mathrm{ml}$ of extracting solution was added to each flask which was shaken at $200 \mathrm{epm}$ or more for 30 minutes at a room temperature, afterward extracts were filtered through Whatmann filter paper \# 42, then phosphorus was analyzed by colorimetry or inductively coupled plasma emission spectroscopy using a blank and standards prepared in the Olsen P extracting solution (Hodges, 2000).

\subsubsection{Identification of Exchangeable Cations $\left(\mathrm{Ca}^{2+}, \mathrm{Mg}^{2+}\right)$ by Atomic Absorption Spectrophotometry}

$10 \mathrm{~g}$ of soil was poured into a tube percolation mixing soil with a defined amount of quartz sand, after the bulb tube surmounting the percolation was filled of $500 \mathrm{ml}$ ammonium acetate $(77.08 \mathrm{~g} / \mathrm{l})$. The percolation took place during about 8 hours. Then percolate was collected into a $500 \mathrm{ml}$ flask. Finally, the percolating was up to $500 \mathrm{ml}$ with a solution of ammonium acetate (Aubert, 1978).

The Measurement of calcium rates was done by establishing a calibration range of $0,4,8,12,16$ and 20 ppm from $\mathrm{Ca}^{+2}(40 \mathrm{ppm})$ solutions. The extract solution was diluted to obtain a concentration of less than $20 \mathrm{ppm}$ (Aubert, 1978). The measurement of magnesium rates was done by establishing a calibration range of 1, 2, 3, 4 and $5 \mathrm{ppm}$ from magnesium solutions (20 ppm) each complete $100 \mathrm{ml}$ flask, with distilled water (Aubert, 1978).

\subsection{Statistics Analysis}

The average concentrations of various parameters analyzed are affected by an analysis of variance using the Fisher's exact test at $\mathrm{P}=5 \%$ using the software SPSS 8.0 for windows.

\section{Results and Discussion}

We note that the non re-vegetated plots recorded an increased $\mathrm{pH}$ values over time: the reported $\mathrm{T} 1$ (summer) $\mathrm{pH}$ is lower than that of autumn (T2) which is lower than that of winter (T3) (Figure 4.a).There is a significant increase of $\mathrm{pH}(\mathrm{p}<0.05)$ in $\mathrm{T} 2$ compared to $\mathrm{T} 1$ on control plots (8.37 compared to 8.04), S14 (8.46 compared to 7.99), D10 (8.52 compared to 8.06), D14 (8.43 compared to 8.04), D24 (8.65 compared to 7.97). There is also a significant increase of $\mathrm{pH}(\mathrm{p}<0.05)$ in T2 compared to T3 on the plots: D10 (8.52 compared to 8.05), D14 (8.43 compared 8.09 ) and D24 (8.65 compared 8.13). Moreover, there is a significant $\mathrm{pH}$ decrease at $\mathrm{p}<0.05$ in $\mathrm{T} 3$ on the plots of $\mathrm{D} 10$ and D14 relative to the non Acacia plots (8.05, 8.09 compared to 8.29). In fact, these results are closely related with the seasonal variations in $\mathrm{pH}$, since $\mathrm{pH}$ rates decrease in hot dry weather and increase in rainy and cold weather (Gasser, 2011).However, the decrease in $\mathrm{pH}$ levels in $\mathrm{T} 3$ under a vegetative cover may be due to a release of protons $\left(\mathrm{H}^{+}\right)$during the uptake of cations by roots (Bye, 1999). In addition, the root exudates may indirectly lead to a decrease in $\mathrm{pH}$ because it stimulates the proliferation of soil microorganisms that synthesize organic acids and thus acidifies the soil (Davet, 1996; Waligora, 2010). The activity of soil microorganisms also depends on the temperature, moisture and soil texture (Lundquist et al., 1999; Steenwerth et al., 2008). Nevertheless, it was observed in laboratory conditions that rhizobia decreases soil $\mathrm{pH}$; while Bradyrhizobia trends to increase it (Dubey, 2011). It was found however that the $\mathrm{pH}$ is a significant factor that affects the nodulation in soils mines with a high rate of nodulation at a pH which is between 5.5 and 7.2 and a low rate to a pH below 5.5 (Zahran, 1999). Meanwhile, alkaline soils with a $\mathrm{pH}$ greater than or equal to 7.8 limit accessibility to Iron, Zinc, Manganese and mainly Boron and Phosphorus in soil, thereby reducing the Nitrogen fixation (Graham \& Allan, 2002)

We found, a deficiency of exchangeable Magnesium for every plot at various times (T1, T2, T3) (Figure 4.b), with rates well below the standards that vary between $10 \%$ and $20 \%$ (Reuter et al., 1997). In fact, an excess of Calcium causes a Magnesium deficiency. However, an excess of Potassium inhibits the absorption of magnesium (Pousset, 2002). Erosion could also be one of the main causes of magnesium deficiency (Boyer, 1978). Thus, the soil is moderately calcareous (Figure 4.c), however, there is a significant decrease at $\mathrm{p}<0.05$ in the total content of 
limestone at T2 in S14 plots (15.32\%) compared to bare soil $(18.55 \%)$ and a significant increase $(\mathrm{P}<0.05)$ at $\mathrm{T} 3$ in D24 plots (19.22\%) compared to non Acacia plots (18.45\%). Similarly, we recorded a significant increase $(\mathrm{p}<0.05)$ at T2 and T3 compared to T1 in Myc plots $(18,12,12 \%$ and $19 \%$ compared to $12.83 \%)$ and mix $(18.9 \%$ and $18.77 \%$ compared to $13.15 \%)$ and a significant increase $(\mathrm{p}<0.05)$ at T3 compared to T1 in S14 plots $(19.1 \%$ compared to $14.53 \%$ ).

This limestone provides divalent calcium $\mathrm{Ca}^{2+}$ that is present especially in the colloid as an exchangeable cation which is the form used by plants (Khan Towhid, 2013). The Calcium content at T2 increases significantly $(\mathrm{p}<0.05)$ in D24 plots compared to control and non Acacias plots ( $88.98 \mathrm{meq} / 100 \mathrm{~g}$ compared to $50.1 \mathrm{meq} / 100 \mathrm{~g}$ and 50.23 $\mathrm{meq} / 100 \mathrm{~g})$. There is also a significant increase $(\mathrm{p}<0.05)$ in T2 compared to T1 in S14 plots $(63.63 \mathrm{meq} / 100 \mathrm{~g}$ compared to $17.93 \mathrm{meq} / 100 \mathrm{~g})$, D24 (88.98 meq/100g compared to $24.75 \mathrm{meq} / 100 \mathrm{~g})$; and mix plots $(50.98$ $\mathrm{meq} / 100 \mathrm{~g}$ compared to $20.03 \mathrm{meq} / 100 \mathrm{~g})$ and a significant increase $(\mathrm{p}<0.05)$ in T2 compared toT3 in D24 plots ( $88.98 \mathrm{meq} / 100 \mathrm{~g}$ compared to $27.16 \mathrm{meq} / 100 \mathrm{~g}$ ) (Figure $4 . \mathrm{d}$ ).

The level of active limestone changes but not significantly. However its content is close to or exceeds $5 \%$ (Figure 4.e). Therefore, limestone solubilization and the gradual release of Calcium can be achieved by acid rainwater or by the biochemical activities of either microorganisms or plant roots (Wierzchos et al., 2003; Salomon, 2006; Coque, 2008). Moreover, the abundance of Calcium ions has an antagonistic effect on other nutrients availability such as Potassium, Iron, Boron, Copper, Manganese, Zinc and signs of deficiency or fading can appear on plants (chlorosis) (Pousset, 2002; Vasant et al., 2009; Ofme, 2011; Morel, 1996). In addition, it inhibits the mineralization of organic matter under the effect of coating (Morel, 1996). Although, land may be rich in total limestone, but relatively poor in active limestone (Pousset, 2002).

The Phosphorus level is low between 1 and 9 ppm. (According to AgSource Laboratories, 2013) (Figure 4.f). However there is an evolution in content over time, where there is a significant increase $(p<0.05)$ of phosphorus in $\mathrm{T} 2$ compared to $\mathrm{T} 1$ in $\mathrm{S} 10$ (6.78 ppm compared to $5.2 \mathrm{ppm}$ ), S14 (7.59 ppm compared to 5.82ppm), S24 (7.16 ppm compared to $3.95 \mathrm{ppm})$, Myc (7.55 ppm compared to $4.67 \mathrm{ppm}$ ) and D24 (7.92 ppm compared to $5.32 \mathrm{ppm}$ ) plots. On The other hand, there is a significant increase $(\mathrm{p}<0.05)$ in T3 compared to T1 in D10 (7.45 ppm compared to $5.07 \mathrm{ppm}$ ) and Mix (7.77 ppm compared to $5.8 \mathrm{ppm}$ ) plots. In fact, Phosphorus is generally low in calcareous alkaline soils. It tends to be insolubilized by the Calcium (Calcium Phosphate and Magnesium) and it is possible that the phosphoric anions precipitate at the contact of the active limestone (Pousset, 2002; Ryan et al., 2001; Baize, 2000). However, Phosphorus is found in organic and inorganic forms. Low Phosphorus availability is due to the larger action of phosphoric anions soluble with $\mathrm{Ca}^{2+}, \mathrm{Mg}^{2+}, \mathrm{Fe}^{3+}$ and $\mathrm{Al}^{3+}$, depending on the geochemical soil properties (Gyaneshwar et al., 2002). Some microorganisms are able to solubilize phosphate minerals while reducing the $\mathrm{pH}$ by the secretion of organic acids which are good chelator of divalent cations such as $\mathrm{Ca}^{2+}$ and they can also form a complex with the metal ions associated with Phosphorus, thus releasing Phosphorus (Jones, 1998; Gyaneshwar et al., 2002; Pradipta, 2008). The mechanism of solubilization of inorganic Phosphorus is provided by organic acids; although the acid phosphatases play a major role in the mineralization of organic phosphorus (Goldstein , 1995; Kim et al., 1997; Rodriguez \& Fraga, 1999). The genera Pseudomonas, Bacillus and Rhizobium are among the most powerful bacteria in the process of dissolution of Phosphorus (Rodriguez \& Fraga, 1999). However, mycorrhizal hyphae make the Phosphorus and certain mineral traces such as Calcium and Zinc available to the host plant (Olsson et al., 1999). In agroforestry, mycorrhizal association contributes to the growth of Acacia species in infertile soils (Dart et al., 1991). Moreover, the dual inoculation by arbuscular mycorrhizal and bacteria that solubilize phosphorus increases the absorption of native soil Phosphorus as well as Phosphorus coming from Phosphate rocks (Goenadi et al., 2000; Cabello et al., 2005).

Total Nitrogen contents have not changed much except for the plots S14 where there has been a significant increase $(p<0.05)$ in T3 compared to T1 $(0.052 \%$ compared to $0.023 \%)$ (Figure $4 . g)$. It is true that the bioavailability of Nitrogen depends primarily on the activity of nitrifying bacteria, but their activity is $\mathrm{pH}$-dependent: they are, in fact, more active when the $\mathrm{pH}$ is between 6.5 and 7.5 and the optimum temperature between $30^{\circ}$ to $35^{\circ}$ Celsius (Biswas \& Mukherjee, 2006). Although, microbiological antagonism may reduce nodulation (Kumara et al., 1974).

Organic matter levels determined are very low ( $<2 \%$ ) (Figure 4.h). This result is in accord with Godwin (1992), who reported that soils in semi-arid regions contain little organic matter, of no more than one percent. Additionally, sandy soils are low in organic matter which generally would make them weak and unproductive (Pousset, 2002). In fact, minerals, organic matter and microorganisms are the key elements in pedogenesis and soil conservation (Bollag \& Leyval, 1998). 


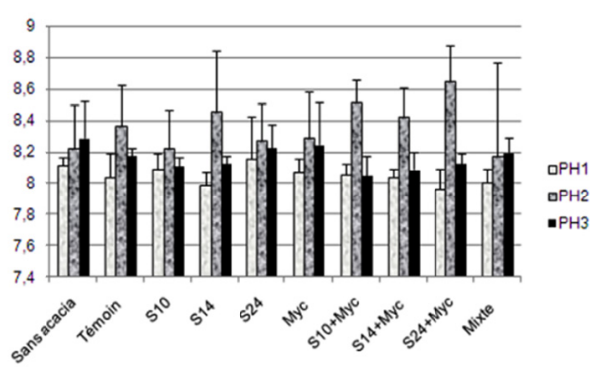

a. Changes in $\mathrm{pH}$ levels

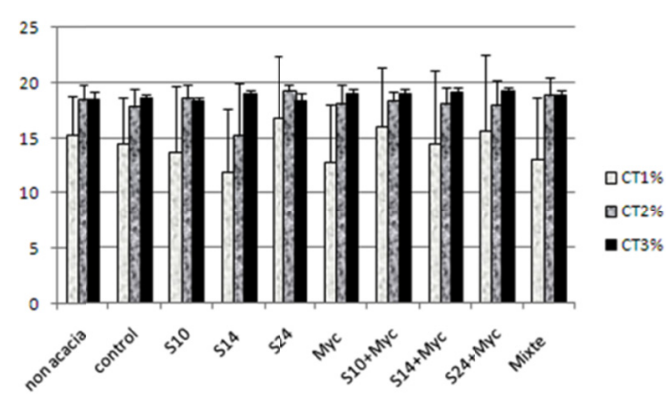

c. Total limestone levels

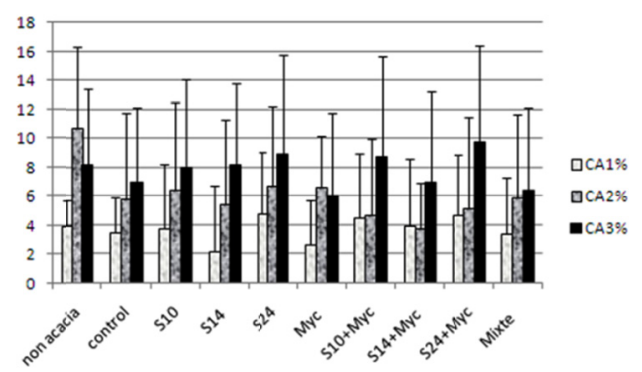

e. Changes in active limestone levels

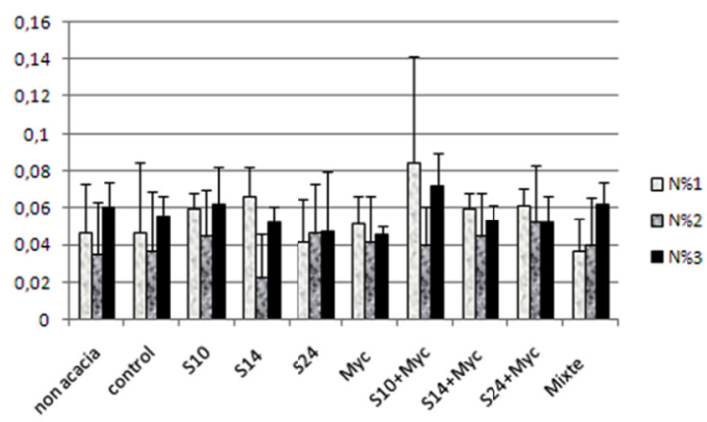

g. Changes in total nitrogen levels

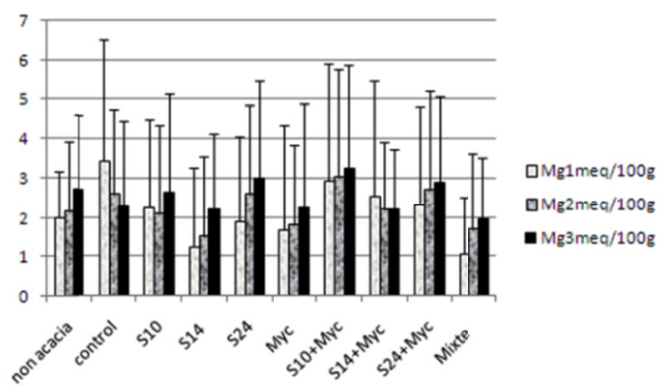

b. Changes in the levels of exchangeable magnesium

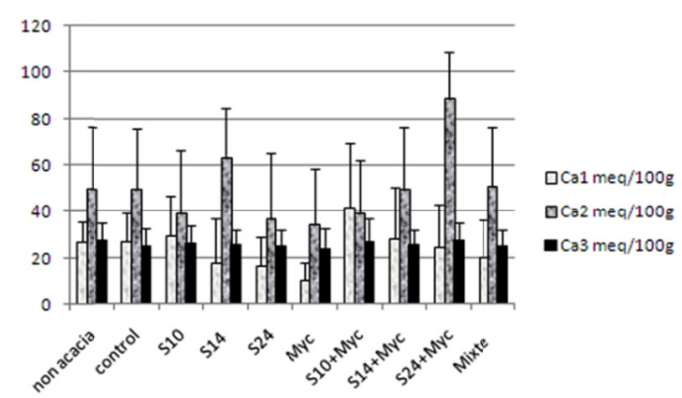

d. changes in the levels of exchangeable calcium

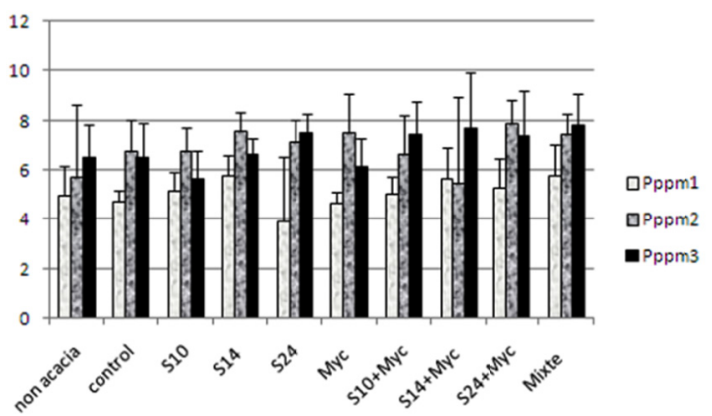

f. Changes in available phosphorus levels

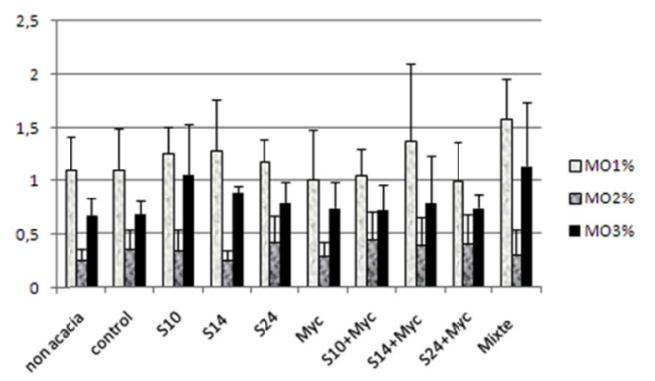

h. Changes in organic matter levels

Figure 4. Changes in the levels of $\mathrm{pH}$, exchangeable magnesium, total limestone, exchangeable calcium, active limestone, available phosphorus, total nitrogen and organic matter during the three trimesters T1, T2, T3 


\section{Conclusion}

After nine months of a bio-re-vegetation, we could achieve at a less alkaline $\mathrm{pH}$ soil and an improvement in phosphorus content. However, the soil calcareous nature and the rate of either active limestone or the exchangeable Calcium results in a small increase in total Nitrogen and organic matter, and makes exchangeable magnesium contents deficient. In perspective, the factor time may be important in this study, so the experimentation can be conducted over a period of two years or more.

\section{Acknowledgements}

We would like to thank Mr A. Bouraoui director of Terga quarry for helping us to make sampling, Ms A. Nehila for her help in the various steps of sampling; I thank so much Mrs Z. Mouffak for correcting my paper and Ms. F. Boukhatem for correcting the microbiology part of the manuscript.

\section{References}

AgSource Laboratorie. (2006). Understanding a soil analyses. Soil Analysis-AgSource Cooperative service. Retrieved from http://agsource.crinet.com/page2903/UnderstandingASoilAnalysis

Aubert, G. (1978). Méthodes d'analyses des sols. Marseille: Centre national de documentation et pédagogique.

Baize, D. (2000). Guide des analyses en pédologie (2nd ed.). Paris, INRA.

Biswas, T. D., \& Mukhherjee, S. K. (2006). Text book of soil science (2nd ed.). edition Tata McGraw-Hill.

Blamire, J. (2003). e-Learning for Quantitative analysis: Kjeldahl Method. Science a distance. Retrieved from http://www.brooklyn.cuny.edu/bc/ahp/SDKC/Chem/SD_KjeldahlMethod.html

Bollag, J. M., \& Leyval, C. (1998). Interactions entre les minéraux des sols, les composés organiques et les microorganismes: Interactions constituants minéraux - constituants organiques - microorganismes du sol sur le cycle et la biodisponibilité des éléments. Montpellier, 16ème congrès Mondial de science du sol.

Boyer, J. (1978). Le calcium et le magnésium dans les sols des régions tropicales-humides et subhumides. Paris, Office de la recherche scientifique et technique outre-mer, $n^{\circ} 35$.

Bye, P. (1999). La truffe, la terre, la vie. Paris, edition INRA.

Cabello, M., Irrazabal, G., Bucsinszky, A. M., Saparrat, M., \& Schalamuck, S. (2005). Effect of an arbuscular mycorrhizal fungus, Glomus mosseae, and a rock-phosphate-solubilizing fungus, Penicillium thomii, in Mentha piperita growth in a soilless medium. Journal of Basic Microbiology, 45(3), 182-189. http://dx.doi.org/10.1002/jobm.200410409

Centre d'expertise en analyse environnementale du Québec et ministère de l'agriculture, des pêcheries et de l'alimentation du Québec. (2003). Détermination de la matière organique par incinération : méthode de perte de feu (PAF), MA. 1010 - PAF 1.0, Ministère de l'Environnement du Québec, p9.

Collin, C. B. (2006). Analyse et reorésentation de la couverture pédologique « application à la caractérisation des unités cartographiques de sols pour le programme I.GCS d'un secteur du Baugeois. Thèse de doctorat en cartographie des sols, Laboratoire de Science du Sol, I.N.H., Angers, et laboratoires Science du Sol et Infosol. INRA, Orléans, France.

Coque, R. (2008). Relief karstique. Encyclopedia Universalis.

Dart, P. J., Umali-Garcia, M., \& Almendras, A. (1991). Role of symbiotic associations in nutrition of tropical acacias. In Turnbull, J. W. (Ed.), Advances in tropical acacia research (pp. 13-19). Canberra, ACIAR: Proceedings $\mathrm{N}^{\circ} 35$.

Davet, P. (1996). Vie microbienne du sol et production végétale. Paris, edition INRA.

Diouf, D., Forestier, S., Neyra, M., \& Lesueur. (2003). Optimization of inoculation of Leucaena leucocephala end Acacia mangium with rhizobium under green house conditions. Ann. For. Sc, 60, 379-384.

Dubey, Y. P. (2011). Rhizobia - As ameliorant to soil reaction. African Journal of Microbiology Research, 5(24), 4091-4096. http://dx.doi.org/10.5897/AJMR11.013

Gasser, M. O. (2011). Variabilité temporelle dans les analyses de sols. Comité ad hoc échantillonnage des sols Drummondville: institut de recherche et de développement en agroenvironnement(IRDA). Québec. Retrieved from http://www.craaq.qc.ca/UserFiles/File/Comites/Adhoc_echantillon_champ/Gasser_24_02_2011_PPT. pdf 
Godwin, R. G. (1992). Le génie agricole au service du développement: production vivrière en zones de faible pluviosité -façons culturales appropriées. Bulletin des services agricoles de la FAO 83.

Goenadi, D., Siswanto, H., \& Sugiarto, Y. (2000). Bioactivation of poorly soluble phosphate rocks with a phosphate solubilizing fungus. Soil Science Society of America Journal, 64(3), 927-932.

Goldstein, A. H. (1995). Recent progress in understanding the molecular genetics and biochemistry of calcium phosphate solubilization by Gram negative bacteria. Biology, Agriculture and Horticulture, 12(2), 185-193. http://dx.doi.org/10.1080/01448765.1995.9754736

Graham, P., \& Allan, D. (2002). Symbiotic Nitrogen Fixation: The Symbiosis between Legumes and Rhizobia .Course on line, department of soil, water and climate: University of Minnesota. Retrieved from http://www.soils.umn.edu/academics/classes/soil3612/Symbiotic_Nitrogen_Fixation/Environmental.htm

Gyaneshware, P., Naresh, K. G., Parekh, L. J., \& Pool, P. S. (2002). Role of microorganisms in improving P nutrition of plants. Plant and Soil, 245(1), 83-93. http://dx.doi.org/10.1023/A:1020663916259

Hodjes, S. C. (2000). Methods of Phosphorus Analysis for Soils, Sediments, Residuals, and Waters. Southern Cooperative Series Bulletin $n^{\circ}$ 396. Publishing Institution: North Carolina State University. Retrieved from http://www.soil.ncsu.edu/sera17/publications/sera17-2/pm_cover.htm

Jones, D. L. (1998). Organic acids in the rhizosphere -a critical review. Plant soil, 205(1), 25-44. http://dx.doi.org/10.1023/A:1004356007312

Khan Towhid, O. (2013). Soils: Principals, Properties and Management. Springer Dordrechi Heidelberg: New York, London.

Kim, K. Y., Jordan, D., \& Krishnan, H. B. (1997). Rahnella aqualitisa bacterium isolated from soybean rhizosphere, can solubilize hydroxyl apatite. FEMS Microbiology Letter, 153(2), 273-277. http://dx.doi.org/10.1016/S0378-1097(97)00246-2

Kumara, R., Abhisivar, S., \& Siende, S. T. (1974). Inhibition of groundnut Rhizobium in Indian Soils. Proceeding of Indian National Science Academy, 40B(5), 535-539.

Lundquist, E. J., Scow, K. M., Jackson, L. E., Uesugi, S. L., \& Johnson C. R. (1999). Rapid response of soil microbial communities from conventional, low input and organic farming systems to a wet/dry cycle. Soil Biology and Biochemistry, 31(12), 1661-1675. http://dx.doi.org/10.1016/S0038-0717(99)00080-2

Mansouri, L. M. (2011). Production d'inoculum de Rhizobium nodulant Acacia Saligna pour revégétaliser la carrière de Terga (Ain Témouchent). Mémoire de magister, laboratoire de biotechnologie des rhizobia et amélioration des plantes. Département de biotechnologie. Université d'Oran es Sénia.

Maslin, B. R., \& Mc Donald, M. W. (2004). Acacia Search - Evaluation of Acacia as a woody crop option for southern Australia: Acacia saligna (Labill.) H. Wendl. Rural Industries Research and Development Corporation. Barton, ACT (pp. 204-214).

Morel, R. (1996). Les sols cultivés (2nd ed.). Paris: Lavoisier.

Ofme. (2011). Sol acide? Sol calcaire? Conséquences pour la forêt? .Centre régionale de la propriété forestière, région PCA Fiche $n^{\circ} 273402$.

Olsson, N. P. A., Thingstrup, I., Jakobsen, I., \& Baath, E. (1999). Estimation of the biomass of arbuscular mycorrhizal fungi in a linseed field. Soil Biology and Biochemistry, 31(13), 1879-1887. http://dx.doi.org/10.1016/S0038-0717(99)00119-4

Philipps, J., \& Hayman, D. S. (1970). Improved procedure for clearing roots and staining plastic and vesicular-arbuscular mycorrhizal fungi for rapid assessment of infection . Trans. Br. Mycol. Soc, 55, 545-554.

Pousset, J. (2002). Guide engrais vert et fertilité des sols (2nd ed.). Agrdécision, Groupe France Agricole (GFA).

Pradipta, K. M. (2008). Textbook of environmental Microbiology. New Delhi (India), International Publishing House Pvt. Ltd.

Reuter, D. J., Robinson, J. B., \& Dutkiewicz, C. (1997). Plant Analysis: An Interpretation Manual (2nd ed.). Victoria, Collingwood: CSIRO Publishing.

Robert, M. (1996). Le sol: Interface dans l'environnement, ressources pour le développement. Paris, Milan, Barcelone: Masson. 
Rodriguez, H., \& Fraga, R. (1999). Phosphate solubilizing bacteria and their role in plant growth promotion. Advances in Biotechnology, 17(4-5), 319-339. http://dx.doi.org/10.1016/S0734-9750(99)00014-2

Ryan, J., Estefan, G., \& Abdul, R. (2001). Soil nutrients, sodium and anion analysis: Potassium. Soil and plant Analysis laboratory Manual (2nd ed.). Aleppo, Syria: International center of agriculture research in the dry areas (ICARDA).

Salomon, J. N. (2006). Précis de Karstologie (2 ed.). France, Presses Universitaires de Bordeaux: Pessac édition.

Steenwerth, K. L., Drenovsky, R. E., Lambert, J. J., Kluepfel, D. A., Scow, K. M., \& Smart, D. R. (2008). Soil morphology, depth and grapevine root frequency influence microbial communities in a Pinot noir vineyard. Soil Biology and Biochemistry, 40(6), 1330-1340. http://dx.doi.org/10.1016/j.soilbio.2007.04.031

Tillard, P., \& Drevon, J. J. (1988). Nodulation and nitrogenase activity of chickpea cultivar inoculated with different strains of rhizobium ciceri. Agronomy, 17, 429-441

Vasant, G., Krichnamurthy, V. N., Sudha, G., Manik, D., \& Paranjape, K. (2009). The fertilizer encyclopedia. New Jersey: John Wiley and Sons edition.

Vincent, I. M. (1970). A manual for the practical of root- nodule bacteria. Oxford and Edinburg: Blackwell scientific publication.

Walligora, C. (2010). Racines et sol: un monde de communications et d'équilibres. Techniques culturales simplifiées, $n^{\circ} 57$.

Wierchos, J., De Los Rios, A., Sancho, L. G., Green, A., \& Ascaso, C. (2003). The integrated microscopical study of Antarticen dolithic microorganisms and their microhabitats.In A. H. L. Leiden Huiskes, W. W. C. Gieskes, J. Rozema, R. M. L. Schorno, S. M. Van der Vries, \& W. J. Wolff (Eds.), Antartic Biology in a Global Context (pp. 152-156).

Zahran, H. H. (1999). Rhizobium- legume symbiosis and nitrogen fixation under severe conditions and in an arid climate. Microbiology and molecular biology reviews, 63(4), 968-989.

\section{Copyrights}

Copyright for this article is retained by the author(s), with first publication rights granted to the journal.

This is an open-access article distributed under the terms and conditions of the Creative Commons Attribution license (http://creativecommons.org/licenses/by/3.0/). 